\title{
The Bulbils and Pro-embryo of Lamprothamnus alopecuroides, A. Braun.
}

\author{
BY \\ MARY M'NICOL, B.Sc. \\ Platt Biological Scholar in the University of Manchester.
}

With Plate VIII.

TAMPROTHAMNUS is a genus of the Characeae placed in the subdivision Chareae on account of the presence of only five cells in the crown of the oospore: it differs from Tolypellopsis in the possession of stipular cells and from Lychnothammis and Chara in having the oogonia below the antheridia.

Distribution. The plant has a wide distribution. It occurs in Europe in the countries of Scandinavia, Denmark, Germany, Spain, and England, though in the last-named country it is of very rare occurrence, having been found only in two localities, at Newtown in the Isle of Wight, from which locality it seems now to have disappeared (Groves, '90), and at the Fleet in Dorset (Mansell-Pleydell, '92). It occurs also in Africa (Braun, '67), but is not known in America, Asia, and Australia. The plants which I have investigated were grown from some dried mud sent from the neighbourhood of Port Elizabeth : they have now been growing in a healthy and apparently normal condition for more than two years.

General Features. L. alopecuroides roots in very fine mud or slime, growing to a height of about $15 \mathrm{cms}$. and branching very little. The internodes in the lower part of the plant may be as much as 4 or $5 \mathrm{cms}$. long, the leaves being 5 or $6 \mathrm{cms}$. The internodes decrease rapidly in length towards the apex of the plant, so that the whorls of leaves form a close tuft, which gives the plant that characteristic appearance whence it derives its specific name of alopecuroides. There is no formation of cortical tissue, and the whole plant has a rather delicate appearance. (See Pl. VIII, Fig. I.)

The leaves are generally eight in a whorl, though on nearly every stem there are variations in one or two whorls, which may have seven, nine, or ten leaves, and with greater rarity either less or more than these numbers.

[Annals of Botany, Vo1. XXI, No. LXXXI. January, 1907.] 
The well-developed whorl of long, single-celled, pointed, stipular leaves or bracts occurring directly below the leaves and equal to them in number, is characteristic of the plant, as are also the leaflets springing from the axils of the leaves. Each leaflet has a sharp-pointed, colourless, transparent apex, into which the cell-lumen does not enter (Fig. $5 a$ ). The stipular leaves measure 2 or $3 \mathrm{mms}$. in length and are here quite conspicuous, but the small leaves occurring in the axils of the ordinary leaves can only be seen on close examination. They resemble the stipular leaves in shape, but are much smaller and vary in length even in the same whorl: they are generally less than $\mathrm{I} \mathrm{mm}$. long. In the lower whorls fewer of these leaves are formed, there being two or three less in number than the leaves. In one casc, taken at random, on the lowest nodes of a well-grown plant the number of small upper leaves formed varied from one to six in a whorl.

The development of the stipular leaves and of the axillary leaves has been studied by Giesenhagen ('02), who has shown that all three whorls, leaves, axillary leaves and stipular leaves, arise in a regular manner from cells which become divided into three by two horizontal walls. After regular subdivisions the upper cell gives rise either to an axillary branch or to an axillary leaf, the middle cell forms the foliar leaf and the lowermost cell the stipular leaf.

The plant is monoecious, the oospores, which ripen in autumn, standing singly below the antheridia which are of an orange-yellow colour.

Migula ('97) mentions that the plant may be slightly encrusted with calcium carbonate, but in the specimens on which I worked there was no encrustation except in the case of the oospores, which showed an accumulation of fine granules, but this never extended to the apex of the spore, so that to the naked eye the spores appeared greyish in colour, with a black apex where the hard, dark-coloured lamella was not hidden by the deposit.

The Bulbils. The plants under observation were grown in large glass jars, and being therefore under somewhat abnormal conditions, it is not extraordinary that the oospores were generally incapable of germination, though many seemed to arrive at maturity. The plants, however, showed great vegetative vigour, and reproduced abundantly from the characteristic unicellular bulbils which are produced on the roots. Similar unicellular bulbils occur in Chara aspera, in which species they have been described and figured by Giesenhagen ('02).

The tubercles or bulbils are about I $\mathrm{mm}$. in diameter, and occur on the root node generally in groups of four or five, though larger groups are frequently found. They exhibit no rotation of protoplasm such as occurs in other internodal cells.

Mode of Growth of Tubercles. Tubercles may arise either directly by 
the swelling up of one of the cells of a node bearing rhizoids, or from a rhizoid which has already grown out in the usual manner. In the former case, when the tubercle has attained its maximum size and has become filled with starch grains, one or more rhizoids may grow out from the distal or apical end. These rhizoids may immediately swell up to form new tubercles, which also become filled with starch, so that one or two new tubercles may be formed at the apex of the first tubercle.

The starch grains in these tubercles are smaller than in those first formed, indeed, a secondary tubercle appears always to remain considerably smaller than the first (Figs. II, 12, and I4).

In a similar way the secondary tubercles may give rise to a tertiary tubercle, which in its turn remains smaller than the tubercle from which it springs.

The second way in which tubercles arise is as follows. In a rhizoid which has grown out from the node, is formed an oblique cell-wall, not far from this node (Fig $8 a$ ). The cell so cut off begins to swell, and small starch grains appear (Fig. $8 a, b, c$ ). At the node formed by the oblique wall, further division may occur into four cells which grow out into rhizoids in the manner usual in the Characeae: in these rhizoids, again, cell-walls may be cut off near the base to form secondary tubercles: tertiary tubercles are formed in the same way. Such sequences of two or three tubercles, though frequent, are not by any means usual: large numbers of tubercles may occur in which not one has grown out to form a secondary tubercle. At the base of primary tubercles there is always a small group of cells formed by further division of the four first-formed node-cells, as described by Giesenhagen in Chara aspera. There is no mention in this case of any occurrence of secondary tubercles. Their formation may be due, in the case of the Lamprothammus under observation, to the formation of an unusual amount of starch in the plant, and the necessity of further provision for its storage.

Kuczewski ('06), writing on the subject of the multicellular bulbils of Chara delicatula, mentions that in his laboratory cultures of this species the root bulbils attained a remarkable size and were more plentiful than in nature. It would thus appear that in cultures the tendency is towards the greater development of this vegetative means of reproduction. Kuczewski also notes and figures a 'merkwürdige Erscheinung des Auftretens von Stärkekörnern in den langgestreckten Zellen der Rhizoiden.' In $L$. alopecuroides I have several times noticed the same appearance, but the starch grains in this case were not of the elongated form described by him in C. delicatula, but were rounded or somewhat angular, like those in the root tubercles. It is probable that they act as further supplies of reserve starch.

The rhizoids of Lamprothamnis have a single nucleus embedded in 
the protoplasm a short distance from the apex, the apex itself being occupied by a number of small, round, shining bodies (Glanzkörper), which are constantly in oscillatory motion. The function of these Glanzkörper is disputed by Zacharias ('05) and Giesenhagen ('01), the latter considering them to be statolithic in function, the former holding that they have some function to perform in the thickening of the cell-walls of the rhizoid.

In these tubercles the nuclei are fragmented, a point which Giesenhagen failed to determine in the case of the tubercles of $C$. aspera owing to the difficulty of cutting sections, but it is probable from analogy that fragmentation is the condition there also. The nuclei can be best seen if tubercles are used from which the starch has been wholly or almost wholly withdrawn for the formation of young plants at the node. These tubercles should be fixed with chrom-acetic acid or Flemming's solution and stained with Delafield's haematoxylin or brazilin.

The nuclei resemble the fragmented nuclei of the internodal cells of the plant, but are somewhat more irregular in shape. They are much the same size, and divide similarly by the appearance of a constriction and the subsequent pinching off of a part of the nucleus.

The Pro-embryo. The pro-embryos arising from the rhizoid-nodes appear first as filamentous processes, at the end of which four horizontal walls are formed, thus dividing the filament into five cells, the three uppermost of which form the apex of the pro-embryo (Vorkeimspitze of Pringsheim). Two more walls then arise close to and parallel with the two lowest horizontal walls, thus cutting off two nodal cells; shortly afterwards three vertical walls are formed in the second nodal cell, and then peripheral cells are cut off. From these cells the first leaves are formed. From the cells of the first or rhizoid-node rhizoids are formed.

At this stage the pro-embryo has not appeared above the mud in which the plant grows and has formed no chlorophyll. I found no case in which the 'Vorkeimspitze' had more or less than three cells, though in Chara. the number is four or five. In Tolypella intricata and some species of Nitella the number is two (De Bary, '75). The three cells differ in size: at first the apical cell grows until it is three or four times as long as the others; the protoplasm in it can be seen rotating, whilst the two lower cells are still filled with frothy protoplasm. With further growth the two lower cells become very much larger than the apical cell, which remains comparatively small. The middle cell elongates, and soon after the 'Vorkeimspitze' appears above the surface of the mud it begins to swell and becomes sometimes spherical, though generally remaining elongated (see Figs. 6 and I8). The lowest cell elongates greatly, and.very often becomes turgescent and swells up, but it never becomes spherical as in the case of the middle cell. The cells which become spherical, or nearly so, are very easily 
separable from the cells below, sometimes breaking off at a touch. The size attained by these cells of the 'Vorkeimspitze' is very striking when compared with the cells of the leaves (Figs. I and 5). The lowest cell sometimes attains a length of about $\mathrm{I} 2 \mathrm{~mm}$., whilst the middle cell reaches about half this length.

The first leaf-node becomes divided by three vertical walls into four cells, from three of which superficial cells are cut off and develop into leaves. The fourth cell is regarded as an apical cell, which by further division and growth forms the stem of the plant. The cells of the leafnode are cut off before the cells of the rhizoid-node, hence the leaves begin to develop before the rhizoid cells.

From this first leaf-node (Uebergangsknoten, Pr.), which Pringsheim considers to consist of three imperfect nodes, each producing at most two leaves, arise the first true leaves (folia of Braun) of the young plant. The 'Vorkeimspitze' becomes pushed to one side by the growth of the leaves, so that in older plants it has very much the position of a leaf, from which it is nevertheless distinguishable here by its great size, the constant number of cells, and the fact that no leaflets (foliola of Braun) are formed, as in the case of the other leaves. Only four leaves of the 'Uebergangsknoten' or transitional node develop to any size, and of these the two leaves standing on each side of the apex of the pro-embryo are alike in size, and are larger than the other two leaves, which also resemble each other in size. The leaves of this whorl always remain uneven in length throughout the life of the plant. It can frequently be seen in older plants that in the two largest of the leaves of this node, the cell immediately below the uppermost cell becomes swollen, as in the corresponding cell of the 'Vorkeimspitze' (Fig. I). There is a tendency, especially in the lower nodes of the plant, for the cells to swell in the same way, the wall becoming gradually thinner as the cell expands.

In one stem it was noticed that the first two nodes, which were separated by a long internode, bore leaves having swollen cells, whilst in the four succeeding nodes, which were close together, the leaves consisted of cells of normal size. In the nodes immediately above these, there again occurred long internodes and whorls of leaves having swollen cells. It is not uncommon for isolated leaves of a whorl, or even all the leaves of a single whorl, to show these swollen cells.

These large cells are good objects for observing the fragmentation of nuclei. As in other Characeae there is in each nodal cell throughout life, and in all young cells, a single large nucleus, spherical in shape and generally having a single large nucleolus, though several nucleoli may occur. This nucleus lies embedded in the frothy protoplasm filling the cell : division to form new cells takes place karyokinetically. In the young cell, when cell formation has ceased, elongation begins and a single large vacuole is formed 
in the centre and the nucleus begins to fragment, so that in one of the large swollen cells there may be a hundred or more nuclei.

The fragmented nuclei of the large cells of Lamprothammus resemble those described by Kaiser in Chara foetida (Kaiser, O., '96) to a great extent, but there appear to be a larger number which are elongated in shape than occur in the latter plant. The nuclei are varied and irreguiar in form : many are elongated, and divide by a gradual constriction of the middle portion of the nucleus (Fig. I7). In this figure of the nuclei of one of the swollen cells, various stages are seen : to the right is a nucleus which is just dividing across the middle, the two daughter-nuclei being connected only by a narrow neck. Other nuclei are rounded, or crescent-shaped.

Nordstedt, in referring to the pro-embryo arising from the spore, remarks that in Lychnothammus Wallrothii (an old name for the plant) there occurs an embryo having an oblique node between the primary rhizoid-node (Samenknoten, or node at the apex of the spore from which rhizoids are formed) and the rhizoid-node or 'secondary rhizoid-node' of Nordstedt. Such an extra node I found in many of the pro-embryos formed at the root-nodes, and also in some produced from spores (Fig. 7). In the formation of this extra node an $\mathrm{S}$-shaped wall is formed and a cell then cut off, which later divides into four, as in the node-formation in rhizoid structures (Fig. 7 A). By further division and growth rhizoids are formed, and these spread out in all directions, though they are actually formed in a tuft on one side only of the pro-embryo. This extra node varies in position: it is generally midway between the rhizoid-node proper and the point of origin of the pro-embryo, and is easily distinguishable from the rhizoid-node proper by the oblique wall. This extra or interposed node is by no means of constant occurrence : in the case of the pro-embryos arising from the underground nodes of the plant, taking nearly a hundred cases, I found that the proportion of plants having this extra node was one in three. In the case of the embryos grown from the spores, I was unable to determine the proportion, as the spores germinated so rarely. It is probable that this extra node is formed in embryos originating from a level at a somewhat greater distance below the surface of the mud than that from which the majority originate. The rhizoids of this interposed node would serve both to fix the young plant firmly and to provide it with nourishment, though probably the former function is the more important, as such large food supplies are available in the root tubercles. This hypothesis is borne out by the fact that if several pro-embryonic shoots arise from a single node, they are alike as regards the presence or absence of this extra node.

Pro-embryos may arise on underground nodes on which no roottubercles occur, but, as is to be expected, the young plants generally arise in proximity to the stores of food material. Pro-embryos also very occasionally arise in the axils of the leaves. 
Transitions from rhizoid to pro-embryo. There are sometimes transitions from a rhizoid formation to a pro-embryo (Nordstedt, '66). A long, thread-like rhizoid, divided in the characteristic way by oblique walls, may cut off cells at its apex to form the 'Vorkeimspitze,' leaf-node and rhizoidnode (Fig. 6) as already described. In such a case the extent of the proembryo cannot be defined, unless we consider it to be simply the internode below the rhizoid-node proper, in which the rhizoids are formed by the cutting off of peripheral cells, and all the cells above this rhizoid-node. Nevertheless, as there are so many cases in which an extra oblique node occurs below the rhizoid-node, when the extent of the pro-embryo is obvious, such a distinction is rather arbitrary.

With the further growth of the young plant of Lamprothamnus, as in the case of other Characeae, a branch, having a dome-shaped apical cell capable of continued division and the formation of whorls of leaves, is generally formed at the rhizoid-node proper (Fig. I $b$ ). This branch first grows out at right angles to the pro-embryo, but soon turns upwards to the surface of the mud. Occasionally an accessory pro-embryo arises from the rhizoid-node (Fig. 5).

Pro-embryo arising from the oospore. The few oospores which had germinated did so in late autumn. The pro-embryos formed, seemed weak and liable to the attacks of a fungus: they were all in a young stage, and the 'Vorkeimspitze' cells had not swollen. I found two cases in which an interposed oblique node was formed between the spore and the rhizoidnode (Fig. 7). The primary root, formed from the spore, divides by an oblique wall in the manner characteristic of the rhizoids of the group, and from the node so formed four rhizoids arise. Later, other rhizoids are formed from this node, and extra rhizoids arise from the 'Samenknoten' (Pr.) or primary rhizoid-node (Nordstedt) situated at the apex of the spore.

Abnormal Plants. (I) Springing from a root-node on which were two tubercles, I found a young pro-embryonic plant, which, instead of showing the usual rhizoids springing from the rhizoid-node, showed about nine rounded tubercles of various sizes, evidently formed directly from the nodecells. Not a single cell had grown out in the ordinary way to form a rhizoid. Between the rhizoid-node and the node from which the proembryo sprang, rows of small starch grains were deposited. The grains in the different tubercles were of different sizes, varying directly with the size of the tubercle itself.

(2) Another abnormal case occurred in which at a rhizoid-node showing the S-shaped oblique wall, there arose, together with one or two rhizoids, a rounded tubercle filled with starch grains. The tubercle had formed chlorophyll and was of a bright green colour. Arising from the same node and in close proximity to the tubercle was a single leaf segment made up of about five cells. It would seem that this part of 
the plant must have been exposed to the light, and so had become green. With a view of confirming this I exposed tubercles to the light at the surface of the mud, but in no case could I obtain the formation of chlorophyll.

\section{Summary of Results.}

Under cultivation in jars in which there was no special provision for aeration, but in which the water was from time to time changed, $L$. alopecuroides has flourished vegetatively for several years, showing its characteristic growth and producing an abundant supply of both antheridia and oogonia.

Apparently a very small number of spores are capable of germination, producing a pro-embryo of characteristic growth.

The pro-embryos produced from the oospores resemble those produced from the underground nodes of the plant.

In many cases the pro-embryo differs from that of other Characeae by the interposition of an extra oblique node, from which rhizoids are produced.

In the case of the pro-embryos produced from the rhizoid-nodes bearing tubercles, about 30 per cent. showed this interposed node.

For the most part reproduction takes place by means of pro-embryos, which are formed on the rhizoid-nodes and make use of the starch stored up in the tubercles. Branch pro-embryos are rare.

Sometimes pro-embryos arise from rhizoid-nodes bearing no tubercles, or from the rhizoid-node of another pro-embryo.

The tubercles either originate directly as such, or are formed by the transformation of rhizoids.

The terminal rhizoid of a tubercle may again become transformed into a tubercle containing starch, thus forming a series of two or more tubercles.

The pro-embryos arise at the basal side of the tubercle.

Generally several pro-embryos arise from a node bearing tubercles.

The nuclei of the tubercles are fragmented, as in the case of the internodal cells.

In concluding, I desire to express my sincere thanks to Professor F. E. Weiss, who suggested this piece of work, and whose interest and help have throughout been most valuable to me. 


\section{INDEX OF LITERATURE.}

DE BARY ('75): Zur Keimungsgeschichte der Charen. Bot. Zeitung, vol. xxxiii, I875, trans. in Journal of Botany, 1875 .

Braun, A. ('52): Ueber die Richtungsverhältnisse der Saftströme in den Zellen der Charen. Ber. d. kgl. Akad. d. Wiss. zu Berl., $185^{2}$ and 1853 .

('67): Die Characeen Afrikas. Ber. d. kgl. Akad. d. Wiss. zu Berl., i867.

Braun and Nordstedt ('82): Fragmente einer Monographie der Characeen. Ber. d. kgl. Akad.

d. Wiss. zu Berl., 1882 .

DeBsk ('97): Beobachtungen über Kerntheilung bei Chara fragilis. Jahrb. für wiss. Bot., 1897 .

-8) : Weitere Beobachtungen an Chara fragilis, t. c. 1898.

GIESENHAGEN ('01): Ueber innere Vorgänge bei der geotropischen Krümmung der Wurzeln der

Charen. Ber. der deutsch. bot. Gesell., Band xix.

('02): Untersuchungen über die Characeen. (I. Die Wurzelknöllchen der Characeen.

Flora, Bd. 82, Jahrg. I 896. II. Der Bau der Sprossknoten bei den Characeen. Flora,

Bd. $83, \mathrm{I} 897$, and $\mathrm{Bd} .85, \mathrm{I} 898$.

Groves, H. AND J. ('90) : Notes on the British Characeae. Journ. of Bot., I89o.

KaISER, O. ('96): Ueber Kerntheilung der Characeen. Bot. Zeitung, I896.

KuCZewski, O. ('06): Morphologische u. biologische Untersuchungen an Chara delicatula $\mathrm{f}$.

bulbillifera. Beihefte zum bot. Centralblatt, 1906.

MANSELL-Pleydell ('92): On the occurrence of Lamprothamnus alopecuroides in Dorsetshire.

Migula ('97) : Die Characeen. Rabenhorst's Kryptogamenflora, i 897.

NoRDSTEDT, O. ('66) : Några iakttagelser öfver Characeernas gröning. Lunds Univers. Årsskrift I. II.

Pringsheim ('62): Ueber die Vorkeime der Charen. Monatsb. d. kgl. Akad. d. Wiss. zu Berlin, I 862.

('63) : Ueber die Vorkeime u. die nacktfüssigen Zweige der Charen. Jahrb. für wiss. Bot., vol. iii, I863.

Vines ('78): Pro-embryo of Chara. Journ. of Bot., 1878.

Wahlstedt U. NoRdstedt ('75): Ueber die Keimung der Characeen. Flora, 1875.

ZACHARIAS ('05): Ueber Statolithen bei Chara. Ber. der deutsch. bot. Ges., I905.

\section{EXPLANATION OF PLATE VIII.}

\section{Illustrating Miss $\mathrm{M}^{\mathrm{C}} \mathrm{Nicol's} \mathrm{paper} \mathrm{on} \mathrm{Lamprothammus.}$}

pa. pro-embryonic apex; $l n$. leaf-node; $r . n$. rhizoid-node; $i, r . n$. interposed oblique rhizoidnode ; $r$. rhizoid ; $b$. branch with dome-shaped apical cell.

Fig. I. Lamprothamnus alopecuroides. Natural size.

Figs. 2, 3, 4. Successive stages in growth of pro-embryo.

Fig. 5. Young plant from the rhizoid-node of which an accessory pro-embryo has arisen.

Fig. 5 A. Characteristic sharp apex of leaflet.

Fig. 6. Transition from rhizoid to pro-embryo.

Fig. 7. Pro-embryo arising from an oospore, and showing an interposed root-node.

Fig. 7 A. Node of rhizoid showing characteristic formation of four cells. This figure has been accidentally inverted in lithographing.

Fig. $8 a, b, c$. Stages in the formation of a root tubercle. In $a$ starch is beginning to be formed. In the other tubercles the presence of starch is indicated by a wash. 


\section{$70 M^{c}$ Nicol. - The Bulbils and Pro-embryo of Lamprothamnus.}

Fig. 9. Fully formed tubercle.

Figs. Io, II. Beginning of formation of secondary tubercle.

Fig. I 2. Fully formed secondary tubercles.

Fig. I3. Case in which the primary tubercle has remained elongated whilst the secondary tubercles have become spherical.

Fig. I4. Sequence of 3 tubercles.

Fig. 15. Group of tubercles showing primary, secondary, and tertiary tubercles in process of formation.

Fig. I6. Fragmented nuclei of a root tubercle, $s$. Starch grain.

Fig. I 7. Fragmented nuclei of one of the swollen cells of the pro-embryonic apex.

Fig. 18. Pro-embryo formed from tubercle near the surface of the mud, and consequently shortened in growth. A young pro-embryo is also seen to the right. 
Annals of Botany.

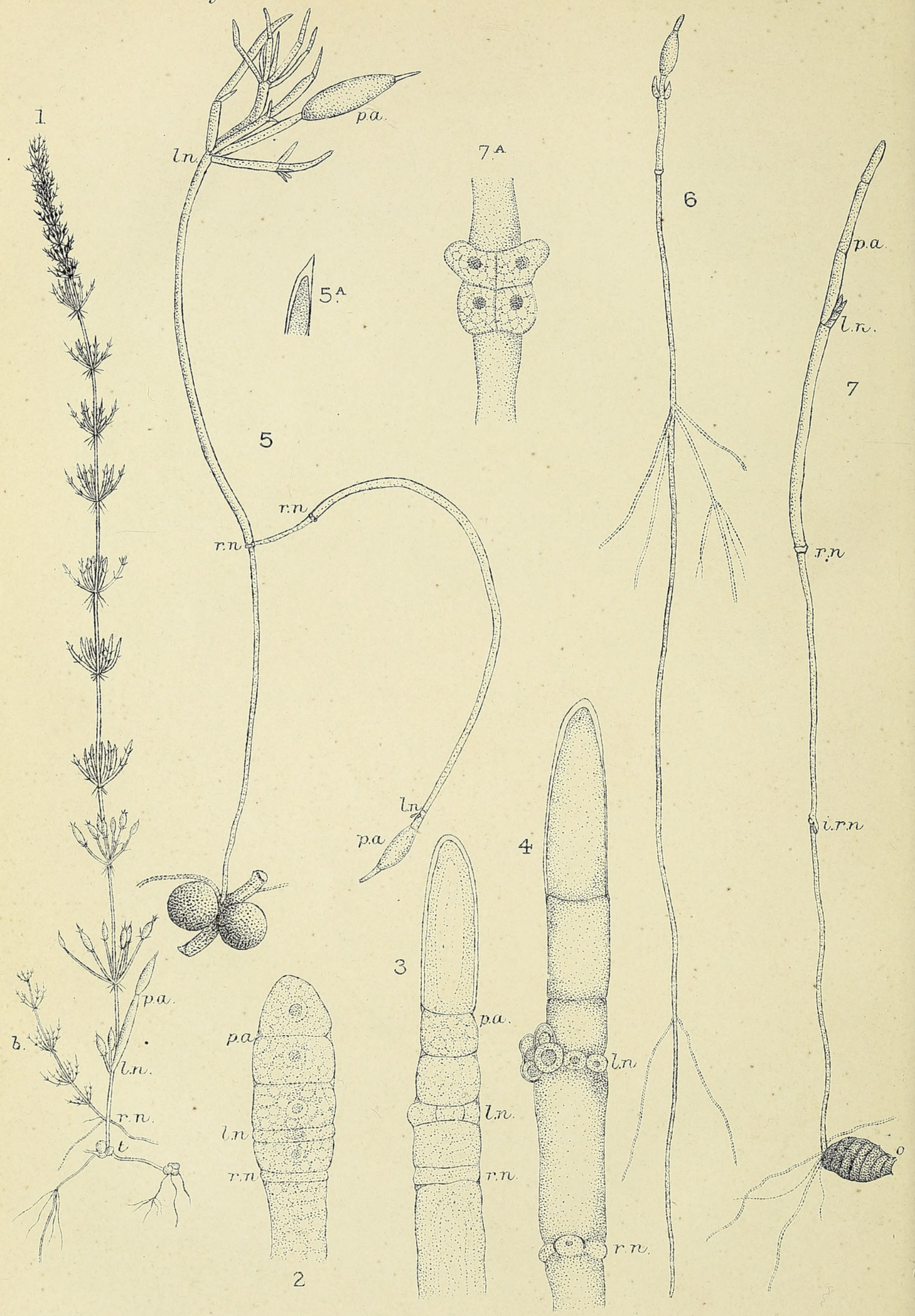

M.M.N. del.

MC NICOL LAMPROTHAMNUS. 
Vol.XXI PL. VIII.

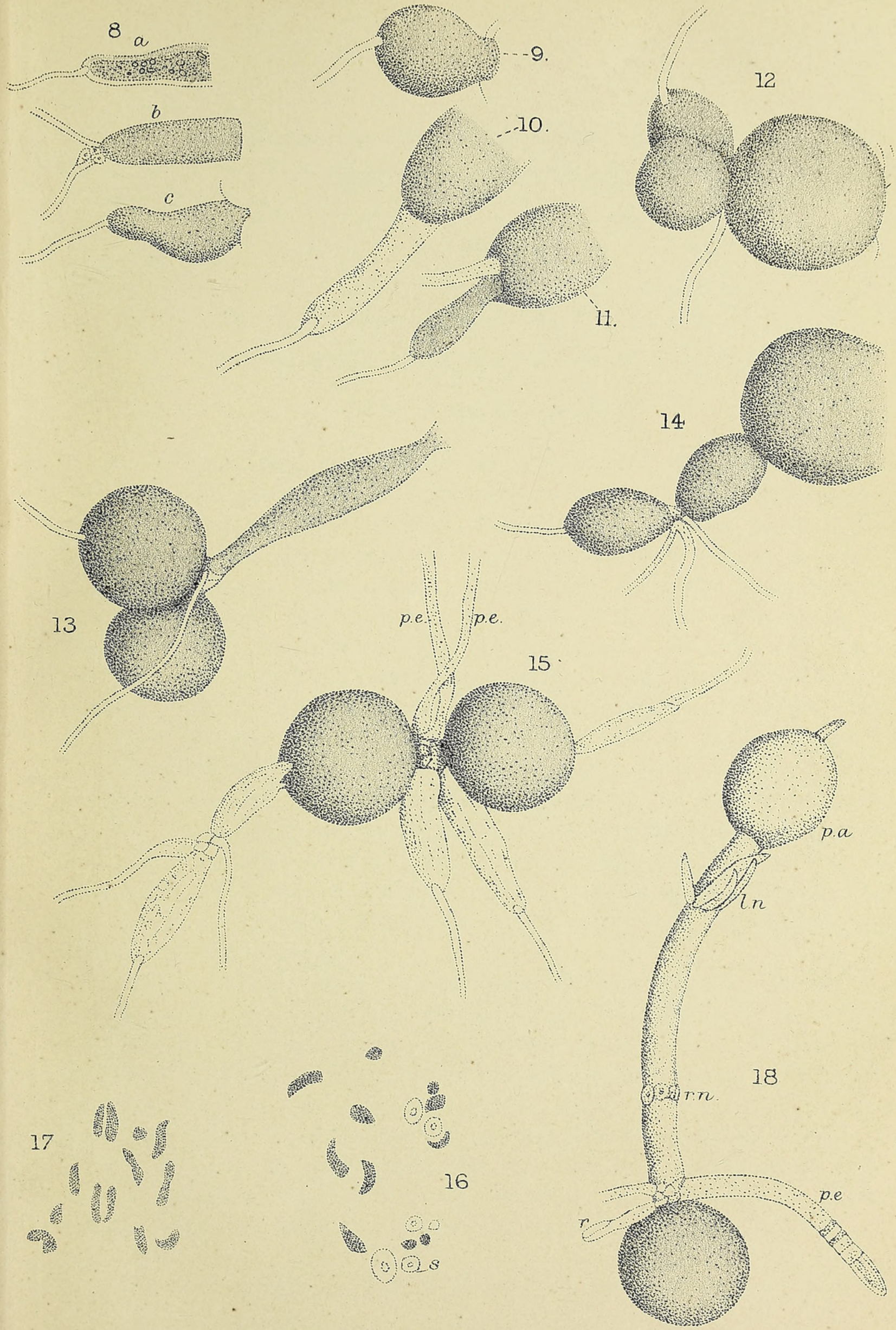

Huth, Lith London 


\section{$2 \mathrm{BHL}$ Biodiversity Heritage Library}

McNicol, Mary. 1907. "The bulbils and pro-embryo of Lamprothamnus alopecuroides, A. Braun." Annals of botany 21, 61-70. https://doi.org/10.1093/oxfordjournals.aob.a089124.

View This Item Online: https://www.biodiversitylibrary.org/item/235747

DOI: https://doi.org/10.1093/oxfordjournals.aob.a089124

Permalink: https://www.biodiversitylibrary.org/partpdf/318861

\section{Holding Institution}

Smithsonian Libraries

\section{Sponsored by}

Biodiversity Heritage Library

\section{Copyright \& Reuse}

Copyright Status: Not in copyright. The BHL knows of no copyright restrictions on this item.

This document was created from content at the Biodiversity Heritage Library, the world's largest open access digital library for biodiversity literature and archives. Visit BHL at https://www.biodiversitylibrary.org. 